\title{
Exercise-induced bronchial lability and atopic status of families of infants with wheezy bronchitis
}

\author{
PETER KÖNIG and SIMON GODFREY \\ From the Department of Paediatrics, Cardiothoracic Institute and Brompton Hospital, Fulham Road, London
}

\begin{abstract}
König, P., and Godfrey, S. (1973). Archives of Disease in Childhood, 48, 942. Exercise-induced bronchial lability and atopic status of families of infants with wheezy bronchitis. Exercise tests and skin tests were carried out in 38 relatives of 16 infants with wheezy bronchitis and 24 relatives of 10 normal infants.

Positive skin tests were found in $57 \%$ of all relatives and $53 \%$ of healthy relatives of the wheezy bronchitis group, compared with $29 \%$ of all relatives and $20 \%$ of healthy relatives in the control group. Increased bronchial lability on exercise was found in $29 \%$ of healthy relatives in the wheezy group, but in only $5 \%$ of relatives of the control infants.

These differences were statistically significant, showing that both atopy and increased bronchial lability on exercise were more frequent among relatives of infants with wheezy bronchitis than in a normal population. This is very similar to the findings in the families of older children with asthma, suggesting a common family background of these diseases.
\end{abstract}

The relation between wheezy bronchitis in infancy and asthma in childhood has aroused much interest and has been the subject of controversy in published reports. Most previous studies have tried to establish relations by looking for hallmarks of atopy or allergy in the children themselves or in their families (Williams and McNicol, 1969; Freeman and Todd, 1962; Buffum, 1963). The data of Boesen (1953) suggested that about $17 \%$ of wheezy infants actually developed asthma.

Increased bronchial lability, which is revealed by exercise, plays an important role in asthma (Jones, Buston, and Wharton, 1962) and apparently also in wheezy bronchitis (König, Godfrey, and Abrahamov, 1972). We have previously shown

Received 5 June 1973. that a high proportion of relatives of asthmatic children have an abnormal bronchial lability and a high incidence of atopy (König and Godfrey, 1973). We therefore decided to study the incidence of atopy and exercise-induced bronchial lability in the families of wheezy infants and in families of normal infants.

\section{Subjects and methods}

Studies were carried out on 38 first-degree relatives (parents and sibs) of 16 infants with wheezy bronchitis. The infants were selected from the wards or outpatient clinics. They were considered to have wheezy bronchitis if they were below 4 years of age and suffered from generalized airways obstruction with expiratory wheezing. In 9 children this was their first such attack, and the remainder had several previous similar episodes. The mean age and the sex of the propositi and of their relatives are given in Table $I$.

TABLE I

Mean age and sex distribution of the propositi and their relatives

\begin{tabular}{|c|c|c|c|c|c|c|c|c|c|}
\hline \multirow{2}{*}{ Group } & \multicolumn{4}{|c|}{ Propositi } & \multicolumn{5}{|c|}{ Relatives } \\
\hline & \multicolumn{2}{|c|}{ Age (yr) } & \multicolumn{2}{|c|}{ Male : Female } & \multicolumn{2}{|c|}{ Age (yr) } & \multicolumn{3}{|c|}{ Male : Female } \\
\hline $\begin{array}{l}\text { Wheezy bronchitis } \\
\text { Control }\end{array}$ & $\begin{array}{l}\text { Mean } \\
\text { SD } \\
\text { Mean } \\
\text { SD }\end{array}$ & $\begin{array}{l}0 \cdot 7 \\
0 \cdot 8 \\
1 \cdot 5 \\
1 \cdot 3\end{array}$ & $\begin{array}{l}10 \\
5\end{array}$ & $\begin{array}{l}: \quad 6 \\
: \quad 5\end{array}$ & $\begin{array}{l}\text { Mean } \\
\text { SD } \\
\text { Mean } \\
\text { SD }\end{array}$ & $\begin{array}{r}22 \cdot 9 \\
8 \cdot 2 \\
25 \cdot 7 \\
10 \cdot 5\end{array}$ & $18:$ & & $\begin{array}{l}20 \\
11\end{array}$ \\
\hline
\end{tabular}


The families of 10 infants who had never wheezed provided a control group of 24 subjects. 3 of these children were in hospital with illnesses not connected with the respiratory system, and the rest were children of hospital staff. Some of their details and those of their relatives are also given in Table $I$. The purpose of the study was explained to each relative and they agreed to participate as volunteers.

A standard questionnaire about atopic diseases was completed by all the relatives. On the basis of this questionnaire, the subjects were classified as either having clinical atopy (past or present asthma, hay fever, allergic rhinitis, infantile or flexural eczema) or being healthy if they gave no history of atopic diseases. Subdivision was not possible because of the small numbers.

In all but one of the relatives prick tests were carried out with 24 common allergens.

All relatives who were at least 4 years old and able to co-operate performed a standard exercise test, as described by Connolly and Godfrey (1970). The subject ran on a treadmill for 6 minutes at a speed and slope which would result in a heart rate of about 170 beats per minute. The peak expiratory flow rate (PEF) was measured before, during, and for 15 minutes after the exercise. After 15 minutes a bronchodilator aerosol (salbutamol) was given and a further one-minute run was performed in order to produce maximum bronchodilatation.

The indices were calculated as below. The expected values for PEF were taken from Godfrey, Kamburoff, and Nairn (1970) for children and from Cotes (1968) for adults.

The upper limits of normal (mean +2 SD) for the indices were taken from the data of Silverman and Anderson (1972). The bronchial lability was considered abnormal if either the JLI or the ELI were above $22 \%$.

The means of the indices for different groups were compared by a Student's ' $t$ ' test, while the significance of proportions was determined by the $\chi^{2}$ test. When a relation could logically be in only one direction, a one-sided $\chi^{2}$ test was used. Differences were considered significant when $P<0.05$.

\section{Results}

The questionnaires revealed a family history of atopy in 11 of the 16 infants with wheezy bronchitis compared with 5 of the 10 control infants. The atopic relatives included parents, sibs, grandparents, uncles, and aunts. Of the relatives actually studied, 7 out of 38 in the wheezy bronchitis group had a history of atopy (2 asthmatics, 1 past asthmatic, 4 hay fever), compared with 4 out of 24 controls (1 asthmatic, 2 hay fever, 1 eczema). The results of the skin tests and exercise tests in those first-degree relatives who were actually studied are given in Tables II and III.

Evidence of atopy in the relatives included in the study, as shown by at least one positive skin test, was found in $57 \%$ of those in the wheezy bronchitis group and in $29 \%$ of the normal group (Table III). Even more impressive is the difference between the healthy relatives in both groups. In these subjects skin tests were positive in $53 \%$ of the wheezy bronchitis group and in only $20 \%$ in the control group. These differences were statistically significant both for the whole group and for the healthy relatives alone. The mean number of positive skin tests per subject was significantly higher in the wheezy bronchitis relatives than in control relatives when all relatives or healthy relatives were considered, but not when the relatives with atopic diseases were compared.

The healthy relatives of the children with wheezy bronchitis had a significantly lower mean resting PEF than the healthy relatives of the controls and their mean exercise lability index was significantly higher. There were no significant differences in the indices of bronchial lability when the relatives with clinical atopy from the two groups were compared. Of the healthy relatives of wheezy infants, $29 \%$ showed an increased bronchial lability compared with only $5 \%$ of the healthy relatives of the control infants. This difference was significant.

The relation between positive skin tests and increased exercise-induced bronchial lability is shown in Table IV. None of these relations were significant in either group.

In the wheezy bronchitis group 9 healthy relatives had an increased bronchial lability. In 6 of them

$$
\begin{array}{ll}
\text { Resting PEF \% } & =\frac{\text { Initial PEF }}{\text { Expected PEF }} \times 100 \\
\% \text { Rise } & =\frac{\text { Highest PEF during exercise }- \text { Initial PEF }}{\text { Initial PEF }} \times 100 \\
& =\frac{\text { Initial PEF }- \text { Lowest PEF after exercise }}{\text { Initial PEF }} \times 100 \\
\text { Exall } & =\frac{\text { Highest PEF during exercise }- \text { Lowest PEF after exercise }}{\text { Initial PEF }} \times 100 \\
\text { Jones Lability Index (JLI, after } & =\frac{\text { Highest PEF during exercise or after bronchodilator }- \text { Lowest PEF }}{\text { Expected PEF }} \times 100 \\
\text { Jones, 1966) } &
\end{array}
$$


TABLE II

Mean values for the indices of exercise lability and positive skin tests per subject in the different groups

\begin{tabular}{|c|c|c|c|c|c|c|}
\hline & $\begin{array}{l}\text { Resting } \\
\text { PEF \% }\end{array}$ & $\%$ Rise & $\%$ Fall & ELI & JLI & $\begin{array}{l}\text { No. of positive skin tests } \\
\text { per subject }\end{array}$ \\
\hline $\begin{array}{l}\text { Wheezy bronchitis } \\
\text { All relatives (no. = 38) } \\
\text { Mean } \\
\text { SEM } \\
\text { Healthy relatives }(\text { no. }=31 \text { ) } \\
\text { Mean } \\
\text { SEM } \\
\text { Atopic relatives (no. = 7) } \\
\text { Mean } \\
\text { SEM } \\
\text { Control } \\
\text { All relatives (no. = 24) } \\
\text { Mean } \\
\text { SEM } \\
\text { Healthy relatives (no. = 20) } \\
\text { Mean } \\
\text { SEM } \\
\text { Atopic relatives (no. = 4) } \\
\text { Mean } \\
\text { SEM }\end{array}$ & $\begin{array}{r}90 \\
2 \\
89 \\
2 \\
91 \\
4\end{array}$ & $\begin{array}{r}10 \\
1 \\
10 \\
1 \\
9 \\
2\end{array}$ & $\begin{array}{r}9 \\
2 \\
6 \\
1 \\
19 \\
9\end{array}$ & $\begin{array}{r}19 \\
2 \\
17 \\
1 \\
28 \\
8\end{array}$ & $\begin{array}{r}17 \\
2 \\
15 \\
1 \\
24 \\
6\end{array}$ & $\begin{array}{l}2 \cdot 1 \\
0.4 \\
1 \cdot 7 \\
0.4 \\
3 \cdot 6 \\
1 \cdot 2\end{array}$ \\
\hline
\end{tabular}

ELI, Exercise Lability Index; JLI, Jones Lability Index (Jones, 1966).

TABLE III

Prevalence of increased bronchial lability and positive skin tests in the different groups

\begin{tabular}{|c|c|c|c|c|c|}
\hline & No. & $\begin{array}{l}\text { Normal } \\
\text { lability }\end{array}$ & $\begin{array}{l}\text { Abnormal } \\
\text { lability }\end{array}$ & $\begin{array}{l}\text { Skin test } \\
\text { negative }\end{array}$ & $\begin{array}{c}\text { Skin test } \\
\text { positive }\end{array}$ \\
\hline $\begin{array}{l}\text { Wheezy bronchitis } \\
\text { All relatives } \\
\text { Healthy relatives } \\
\text { Atopic relatives }\end{array}$ & $\begin{array}{r}38 \\
31 \\
7\end{array}$ & $\begin{array}{r}27(71) \\
22(71) \\
5(71)\end{array}$ & $\begin{array}{r}11(29) \\
9(29) \\
2(29)\end{array}$ & $\begin{array}{l}16(43) \\
14(47)^{\star} \\
2(29)\end{array}$ & $\begin{array}{r}21(57) \\
16(53) \\
5(71)\end{array}$ \\
\hline $\begin{array}{l}\text { Control } \\
\text { All relatives } \\
\text { Healthy relatives } \\
\text { Atopic relatives }\end{array}$ & $\begin{array}{r}24 \\
20 \\
4\end{array}$ & $\begin{array}{r}22(92) \\
19(95) \\
3(75)\end{array}$ & $\begin{array}{l}2(8) \\
1(5) \\
1(25)\end{array}$ & $\begin{array}{r}17(71) \\
16(80) \\
1(25)\end{array}$ & $\begin{array}{l}7(29) \\
4(20) \\
3(75)\end{array}$ \\
\hline
\end{tabular}

Note: Percentages in parentheses.

^Skin tests not carried out in one subject.

( $75 \%)$, and in the only labile healthy relative from the control group, the \% Rise was greater than the $\%$ Fall, meaning that their lability was mainly due to bronchodilatation during exercise or after the bronchodilator, and not due to bronchoconstriction after exercise.

Among the atopic relatives in the wheezy bronchitis group there were 2 subjects who had suffered from asthma, one with present and one with a past history of the condition. In both cases they had increased bronchial lability with the \% Fall being greater than the \% Rise. The one atopic
TABLE IV

Relation between skin testing and exercise lability

\begin{tabular}{l|c|c}
\hline & Skin test positive & Skin test negative \\
\hline $\begin{array}{l}\text { Wheezy bronchitis } \\
\text { Exercise positive }\end{array}$ & $5(24)$ & $5(31)$ \\
$\begin{array}{l}\text { Exercise negative } \\
\text { Control }\end{array}$ & $16(76)$ & $11(69)$ \\
$\begin{array}{l}\text { Exercise positive } \\
\text { Exercise negative }\end{array}$ & $1(14)$ & $1(6)$ \\
& $6(86)$ & $16(94)$ \\
\hline
\end{tabular}

Note: Percentages in parentheses. 
TABLE V

Comparison of findings from the present study with those of a previous study on families of children with asthma

\begin{tabular}{|c|c|c|c|}
\hline & $\begin{array}{c}\text { Normal control } \\
\text { families }\end{array}$ & $\begin{array}{l}\text { Wheezy bronchitis } \\
\text { families }\end{array}$ & $\begin{array}{l}\text { Asthma } \\
\text { families }\end{array}$ \\
\hline $\begin{array}{l}\text { Healthy relatives } \\
\text { Positive skin tests } \\
\text { Positive exercise tests }\end{array}$ & $\begin{array}{c}\text { (no. }=20) \\
20 \% \\
5 \%\end{array}$ & $\begin{array}{l}\text { (no. }=31 \text { ) } \\
53 \% \\
29 \%\end{array}$ & $\begin{array}{c}\text { (no. }=25 \text { ) } \\
40 \% \\
32 \%\end{array}$ \\
\hline $\begin{array}{l}\text { Atopic relatives } \\
\text { Positive skin tests } \\
\text { Positive exercise tests }\end{array}$ & $\begin{array}{c}\text { (no. }=4) \\
75 \% \\
25 \%\end{array}$ & $\begin{array}{c}(\text { no. }=7) \\
71 \% \\
29 \%\end{array}$ & $\begin{array}{c}\text { (no. }=28) \\
79 \% \\
39 \%\end{array}$ \\
\hline
\end{tabular}

relative from the control group had hay fever and her $\%$ Rise was larger than her $\%$ Fall.

\section{Discussion}

This study has shown that two important factors in the pathogenesis of asthma, namely increased bronchial lability and atopy, are more frequent in the families of infants with wheezy bronchitis than in the families of normal children.

In a previous study (König and Godfrey, 1973) it was found that $32 \%$ of the healthy relatives of asthmatic children had an increased exercise lability. This compares very closely with our finding of $29 \%$ in the wheezy bronchitis group and contrasts with the $5 \%$ in the control group (Table $\mathrm{V}$ and Fig.).

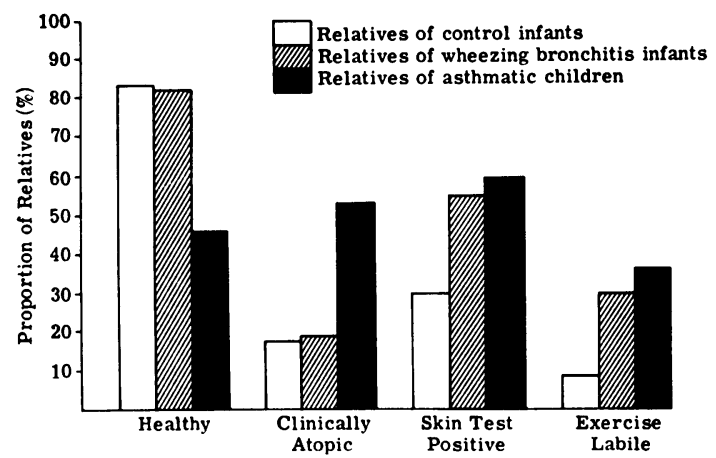

FIG.-The proportion of clinical atopy, positive skin tests, and exercise-induced bronchial lability in relatives of normal infants, of infants with wheezy bronchitis, and of children with asthma.

No marked differences were observed among atopic relatives in any of the three groups (Table V). When the mean values for the indices of exercise lability and the mean number of positive skin tests per subject of the relatives of asthmatic children were compared with those of the present study, it was found that no feature of increased bronchial lability or atopy was significantly higher in the asthma families than in the wheezy bronchitis families. If anything, the mean number of positive skin tests per subject was higher in the healthy relatives of the wheezy bronchitis group than in the corresponding group from the asthma families $(0.005>P>0.025)$.

The pattern of increased exercise lability due mainly to bronchodilatation, as found in the present study in the healthy relatives, was shown previously in nonasthmatic relatives of asthmatic children (König and Godfrey, 1973) and in children with a past history of wheezy bronchitis (König et al., 1972).

Simon and Jordan (1967) found a higher incidence of allergy and family history of wheezing in children with more than one episode of wheezing, as compared with those who had only one episode. In the present study there was no evidence of any significant difference between 'first-time wheezers' and 'repeaters'. There were 15 healthy relatives of the children who had only one episode of wheezing, and of these $9(60 \%)$ had positive skin tests and 4 $(27 \%)$ had positive exercise tests, while the 'repeaters' had 12 healthy relatives of whom $6(50 \%)$ had positive skin tests and $1(8 \%)$ had positive exercise tests.

In conclusion, this study has shown that the incidence of atopy and exercise-induced bronchial lability in the relatives of infants with wheezy bronchitis differs from that of normal infants and is very similar to that in relatives of children with asthma. We believe this is good evidence that there is a common genetic basis for a tendency towards wheezing in infancy and asthma in childhood.

We are grateful to Drs. H. V. L. Finlay and S. T. Tucker for allowing us to study the families of their patients at Hillingdon Hospital, and for their help and that of their nursing staff. We also appreciate the co-operation of our volunteer subjects, young and old. This work was supported in part by a grant from the Medical Research Council. 


\section{REFERENCES}

Boesen, I. (1953). Asthmatic bronchitis in children. Acta Paediatrica, 42, 87.

Buffum, W. P. (1963). The prognosis of asthma in infancy. Pediatrics, 32, 453.

Connolly, N., and Godfrey, S. (1970). Assessment of the child with asthma. Fournal of Asthma Research, 8, 31.

Cotes, J. E. (1968). Lung Function. Blackwell, Oxford and Edinburgh.

Freeman, G. L., and Todd, R. H. (1962). The role of allergy in viral respiratory tract infections. American fournal of Diseases of Children, 104, 330.

Godfrey, S., Kamburoff, P. L., and Nairn, J. R. (1970). Spirometry, lung volumes and airway resistance in normal children aged 5-18 years. British fournal of Diseases of the Chest, 64, 15.

Jones, R. S. (1966). Assessment of respiratory function in the asthmatic child. British Medical fournal, 2, 972.

Jones, R. S., Buston, M. H., and Wharton, M. J. (1962). The effect of exercise on ventilatory function in the child with asthma. British Fournal of Diseases of the Chest, 56, 78.
König, P., and Godfrey, S. (1973). Prevalence of exercise-induced bronchial lability in families of children with asthma. Archives of. Disease in Childhood, 48, 513.

König, P., Godfrey, S., and Abrahamov, A. (1972). Exerciseinduced bronchial lability in children with a history of wheezy bronchitis. Archives of Disease in Childhood, 47, 578.

Silverman, M., and Anderson, S. D. (1972). Standardization of exercise tests in asthmatic children. Archives of Disease in Childhood, 47, 882.

Simon, G., and Jordan, W. S. (1967). Infectious and allergic aspects of bronchiolitis. Fournal of Pediatrics, 70, 533.

Williams, H. and McNicol, K. N. (1969). Prevalence, natural history, and relationship of wheezy bronchitis and asthma in children: an epidemiological study. British Medical fournal, 4, 321.

Correspondence to Dr. S. Godfrey, Department of Child Health, Hammersmith Hospital, Du Cane Road, London W12 OHS. 